\title{
Survival of Private Sector Manufacturing Establishments in Africa: The Role of Productivity and Ownership
}

\author{
Admasu Shiferaw \\ Institute of Social Studies \\ Kortenaerkade 12 \\ 2518 AX The Hague \\ The Netherlands \\ Tel: 31-70-426-0460 \\ Fax:31-70-426-0799 \\ E-mail: admasu@iss.nl
}




\section{Acknowledgements}

I would like to thank Arjun Bedi, Michael Grimm and Robert Sparrow for their comments on an earlier draft of this paper. Comments by anonymous referees have helped me improve the paper substantially. All remaining mistakes and errors are mine. 


\title{
Survival of Private Sector Manufacturing
}

\section{Establishments in Africa: The Role of Productivity}

\section{and Ownership}

\begin{abstract}
:
This paper analyzes the risk of exit for privately-owned manufacturing establishments in a small African economy. It shows that changes in the structure of ownership following an economic reform have important implications on establishment survival. The risk of exit is lower for establishments that belong to multi-unit firms as compared to single-unit establishments suggesting the presence of information and risk sharing mechanisms within a group. Although female-owned businesses tend to be smaller in size, they have better chances of survival than male-owned establishments. The probability of exit also declines significantly in establishment size and productivity.
\end{abstract}

JEL Classification: D21; L11

Keywords: Firm-Survival; Productivity; Ownership-structure; Africa; Ethiopian Manufacturing 


\section{INTRODUCTION}

When firms close down, jobs are destroyed. However, business closure may also increase aggregate productivity if exiting firms are relatively inefficient. Firms' exit decisions have therefore attracted a growing literature because of their implications on the trajectories of employment, productivity and growth at the aggregate level. Bernard and Jensen (2007), for example, show that about $58 \%$ of gross-job-destruction in the U.S. manufacturing during the 1990s was accounted for by plant closure. Geroski’s (1995) review of firm dynamics in developed countries shows that most industries do not experience any shortage of entrants. In fact, overcoming entry barriers is relatively easier than surviving the market especially for small firms during their first few years in business (Bartelsman et al., 2003). In almost all cases surviving firms are larger, older and more efficient than exiting firms reflecting the existence of market forces that ensure the 'survival of the fittest'.

Understanding the nature of firm exit or survival is particularly relevant for countries in SubSaharan Africa where dysfunctional markets are believed to have stifled the entry and growth of small enterprises while tolerating inefficient large incumbents (Collier and Gunning, 1999). Since the mid 1980s, countries in the region have been implementing reforms to build market economies where the private sector plays a leading role. How far these countries have gone in this direction is an interesting question to which firm level studies can provide crucial insights. At present, only a few studies have analyzed firm survival in Sub-Saharan Africa. The first attempt was by McPherson (1995) who estimated a proportional hazard model to assess the risk of exit facing micro and small enterprises in four Southern African countries. He found that contrary to theoretical expectations, the risk of exit does not vary with firm size although growing firms stand better chances of survival ${ }^{1}$. Frazer (2005) studied the survival of

\footnotetext{
${ }^{1}$ See Mead and Liedholm (1998) for other aspects of small firm dynamics in Southern Africa.
} 
Ghanaian manufacturing firms using the RPED (Regional Program on Enterprise Development) dataset for the early 1990s while Söderbom, Teal and Harding (2006) carried out a similar study for Ghana, Kenya and Tanzania. These recent papers on African firms provide strong evidence that the risk of exit declines in firm size and productivity. These findings are consistent with the predictions of market selection models as well as some of the evidence for industrialized countries ${ }^{2}$.

For a sample of small establishments in Ethiopian manufacturing in the mid 1990s, Mengistae (2006) finds a positive effect of firm size on survival. He shows further that the risk of exit declines in the human capital of entrepreneurs while it increases in the degree of competition both from imports and rival domestic firms. Using census based panel data of Ethiopian manufacturing firms, Shiferaw (2007) follows a non-parametric analysis that uncovers a high degree of persistence at the top of the productivity ranking while the majority of establishments at the bottom of the distribution (about 60\%) exited the market in a period of six years, revealing the existence of competitive markets.

The main thrust of survival analysis is to better characterize surviving firms and assess the nature of market selection. Doing so requires reliable measurement of firm specific productivity and the ability to identify the incidences of entry and exit. This paper investigates firm survival in Ethiopian manufacturing and our first contribution to this literature draws from a data advantage. Unlike previous studies on African firms, with the exception of Shiferaw (2007), the current paper uses census-based panel data which is more likely to provide robust hazard estimates since it allows more effective tracking of firm entry and exit than would be possible in survey based datasets that are not always representative. As

\footnotetext{
${ }^{2}$ Following a non-parametric analysis of firm size distributions in nine Sub-Saharan African countries, Van Biesebroeck (2005) also finds some evidence that large firms are more likely to survive.
} 
explained later, the Ethiopian manufacturing census also captures a wider range of industries than the RPED surveys (which cover only four industries) and permits a consistent estimation of industry specific production functions that yield reliable indicators of firm level productivity. A related issue is the estimation method of production functions used to calculate establishment level productivity. In that sense the productivity measures in Shiferaw (2007) are derived from a production function estimation method suggested by Levinsohn and Petrin (2003) which has since been criticized by Ackerberg, Caves and Frazer (2005) for inadequate handling of the simultaneity problem. While using the same panel data as in Shiferaw (2007), the preferred estimation method of production functions in the current paper is the Blundell and Bond (1998) system GMM estimator. Nonetheless, estimation of hazard models using productivity measures obtained from the Levinsohn and Petrin (2003) and the system GMM estimators show similar productivity effects on firm survival. These results are also consistent with the competitive selection reported in Shiferaw (2007) for Ethiopian manufacturing firms but the analysis in this paper goes further to take into account other establishment and industry level covariates that may determine establishment survival.

Since the onset of economic reform in 1991, Ethiopian manufacturing has gone through remarkable changes in the structure of firm ownership. The new investment law has not only removed caps on the level of private investment but also allowed entrepreneurs to run more than one line of business. Investors could thus decide to enlarge a single establishment by reinvesting their profits or run a multi-unit firm with small establishments. The proportion of multi-unit firms has been increasing during the sample period (1996-2002) and they account for about $41 \%$ of manufacturing sector employment and $33 \%$ of the value added. Similarly, the growing role of the private sector in Ethiopian manufacturing has been accompanied by a steady rise in female-owned establishments. The second contribution of the paper is therefore 
to go beyond the traditional covariates of hazard models and analyze the evolving structure of ownership and its implications on establishment survival by comparing multi-unit versus single-unit establishments, and female-owned versus male-owned establishments.

Thirdly, while previous studies on African firms controlled only for industry fixed effects, the survival analysis in this paper takes into account fixed as well as time varying industry effects $^{3}$. The latter include proxies for industry concentration, entry and exit barriers, business cycles and exposure to international competition. Finally, the paper estimates the probability of exit using discrete-time proportional hazard models which are more effective than competing methods in handling right-censured duration data that are observed in discrete- rather than continuous-time (Cameron and Trivedi, 2005).

The paper is organized in seven sections. Section 2 briefly reviews the literature on firm survival. Section 3 outlines the empirical approach by highlighting the relevant duration models and the choice of covariates. Section 4 introduces the data and provides summary statistics. Section 5 presents the results of the survival analysis while section 6 checks the sensitivity of the results to unobserved heterogeneity. Conclusions are in section 7.

\section{THEORETICAL FRAMEWORK}

Once firms have entered the market, they operate under continuous but varying levels of exit risk. Theoretical models of industrial evolution like the passive learning model of Jovanovic (1982) and the active learning model of Pakes and Ericson (1998) predict that small firms are

\footnotetext{
${ }^{3}$ Mengistae (2006) controls for industry level competition but the survey is confined to small firms in the capital city and spans over two years only.
} 
more likely to exit the market than their large counterparts. These models also predict that the risk of business failure declines over time as firms acquire new competitive skills or as they fully discover their innate efficiencies. However, the business strategies literature suggests that small firms do not need to grow in size in order to survive. The argument is that small firms have the advantages of flexibility and specialization in niche markets that allow them to overcome business failures (Porter, 1990; Caves and Porter, 1977).

Most empirical studies, particularly for developed countries, find positive and statistically significant size and age effects on firm survival in line with market selection models (Geroski, 1995; Bernard and Jensen, 2007). The results are mixed for firms in developing countries. Factor elasticities estimated from production functions often do not obtain significant scale economies in manufacturing, suggesting that small firms may not be particularly at a disadvantage in most industries (Biggs et al., 1995; Little et al., 1987). Similarly, for micro and small enterprises in southern Africa, McPherson (1995) found no significant size effect on survival. However, Frazer (2005), Mengistae (2006) and Söderbom et al. (2006) show clearly that large firms stand better chances of survival.

Identifying the role of productivity has been at the centre of firm survival analysis. If markets work properly, competition would purge industries of inefficient producers. Despite methodological differences in the estimation of productivity, the studies by Frazer (2005) and Söderbom et al. (2006) provide evidence that productivity reduces the risk of exit significantly. In the case of Söderbom et al. (2006) the productivity effect is statistically significant only for small firms. While this might be generally the case, efficiency does not seem to explain the entire survival story. For a group of five African countries, a large 
proportion of exiting firms closed down for non-business reasons, such as the death of the owner or opening up of better opportunities elsewhere (Liedholm et al., 1994). As in McPherson (1995) this finding is based on a sample of micro and small enterprises only. For Ethiopian manufacturing, Shiferaw (2007) shows that while the proportion of exiting firms increases as one goes down the productivity ladder, about a quarter of establishments in the most efficient productivity quintile have also exited the market over a period of six-years.

Factor intensity is often used as an indicator of firms' choice of technology. Standard trade theory claims that capital-intensive industries in economies abundantly endowed with labor would contract or even disappear unless they are protected. However, more capital per person could enhance labor productivity and reduce the hazard of business failure. The latter is a view espoused by theories of industrial evolution that relate firm survival and growth to investment in productivity-enhancing activities (Pakes and Ericson, 1998). Firms' choice of skill intensity may also affect their prospects of success. This could in fact be more relevant than capital intensity particularly for technologically advanced products that require continuous upgrading. The empirical evidence is also mixed in this case. Frazer (2005) finds that for Ghanaian firms capital intensity raises the risk of exit after controlling for industry fixed effects while Söderbom et al. (2006) find no significant effect. For U.S. manufacturing Bernard and Jensen (2007) show that both capital and skill intensity reduce the risk of exit.

Another dimension of firm survival relates to the structure of ownership. Economic reforms in Ethiopia and other African countries have allowed, and at times promoted, local and foreign private investment even in sectors formerly reserved only for public enterprises. In Ethiopia, the investment law has removed caps on the size of investment as well as restrictions on how many lines of business an entrepreneur can engage in. These measures bring about changes in 
the structure of ownership which have implications on survival. For instance, firms partly or fully owned by foreigners may survive longer because of preferential treatments by policymakers or simply because of better access to superior technology. However, one would also expect foreign firms to exit the market if the location-advantages that attracted them such as natural resources or cheap labor are eroded. Gender is another dimension of ownership worth exploring as female entrepreneurs often face more hurdles to establish and successfully run businesses than their male counterparts (Loscocco et al., 1991). McPherson (1995) found that in two out of four African countries that he studied, female-owned small firms exhibited a higher risk of closure. A third aspect of ownership is whether or not an establishment is part of a multi-unit firm. The latter style of organization often seems to enhance performance because of the pool of resources at the firm level such as knowledge, experience and finance that can be shared by individual plants. For UK manufacturing, for instance, Disney, Haskel and Heden (2003) show that being part of a group increases the survival probability as compared to single-unit establishments. Dunne, Roberts and Samuelson (1989) also found that establishments in multi-unit firm in the US manufacturing grow faster than single-unit firms. A recent paper by Bernard and Jensen (2007) shows that although the unconditional probability of exit is much lower for multi-unit firms, this advantage turns out to be statistically insignificant once plant level characteristics are taken into account. No other paper seems to have addressed the significance of this relationship in the context of African manufacturing.

Other forces that influence firm survival operate at the industry level. If an industry is on the upswing with a growing demand, survival might be easier even for inefficient firms, while a downswing might threaten even the well established firms. Ignoring inter industry variation in output growth could therefore undermine the identification of firm level traits of survival. 
In theory, more competition is expected to induce productivity growth by intensifying the exit threat. Accordingly, if trade liberalization exposes industries to direct competition from imports, some producers will be forced to improve productivity or lose market shares leading eventually to closure (Balassa, 1988). Competition could also be rife even in protected industries if the domestic market is not dominated by few players. Industries with high concentration are therefore expected to have lower risks of exit because of weak competition. A related issue is inter-industry variation in entry and exit barriers that would influence the risk of firm closure. Hopenhayn (1992) shows that high entry barriers, due to government policy or collusion among large firms, could reduce the minimum level of productivity needed to stay in the market thereby protecting incumbents. Similarly, costs associated with firm exit such as employee compensation or difficulty to recover fixed assets may delay firm closure although they may not prevent it indefinitely.

The preceding discussion has highlighted key firm and industry characteristics that could determine firm survival. The existing firm level studies on African manufacturing have shown that firm size, age and productivity are inversely related with the risk of exit which is expected in functional markets. This paper provides further evidence on the process of market selection by using more reliable productivity estimates and controlling for a number of industry effects that could influence the probability of exit. Most importantly the paper provides new evidence on two emerging aspects of firm ownership, i.e. female ownership and multi-unit firms, which have not been addressed adequately in previous studies of firm survival in African manufacturing.

The following section outlines the empirical approach that will allow us to put together and give empirical content to the preceding discussion. 


\section{THE EMPIRICAL APPROACH}

(a) Duration Models

The analysis of survival time has a long tradition in biometrics and material sciences. Its application for firm demographics is rather recent starting with the works of Troske (1989) and Audretsch and Mahmood (1994). The subject of analysis is the population distribution of time under risk - firm exit in this case. The cumulative density function $F(t)$ of time under risk or survival time $(T)$ is expressed as:

$F(t)=P(T \leq t), \quad t \geq 0$

where $t$ is a specific value of $T$.

The survivor function $(S)$ is defined as the probability of surviving past time $t$ :

$S(t) \equiv 1-F(t)=P(T>t)$

Because of the right-censoring of survival time, in most applications the prime interest is in the hazard function which is the probability of failure in a short time interval $\Delta t$ conditional on survival until $t$. The hazard function $\lambda(t)$ is expressed as:

$\lambda(t)=\lim _{\Delta t \rightarrow 0} \frac{P(t \leq T<t+\Delta t \mid T \geq t)}{\Delta t}=\frac{f(t)}{S(t)}$

where $f(t)$ is the density of $T$.

The shape of the hazard function conveys an important message about the underlying distribution of survival time. If the derivative of the hazard function with respect to time is positive, i.e., $\lambda^{\prime}(t)>0$, the hazard is said to follow a positive duration dependence, meaning that the risk of failure increases with time. If the derivative is less than zero, there is negative duration dependence and agents will be more likely to survive as time goes by. The event being studied is said to be "memoryless" if the derivative of the hazard is equal to zero. 
Our interest is in estimating a conditional hazard model with firm and industry characteristics:

$$
\lambda(t ; x)=\frac{f(t \mid x)}{1-F(t \mid x)}=\frac{f(t \mid x)}{S(t \mid x)}
$$

There are several parametric and non-parametric approaches to estimate (4). Proportional hazard models like that of Cox (1972) for instance analyze the shift in a baseline hazard function due to a unit change in an explanatory variable. The baseline hazard function $\lambda_{0}(t)$ is common to all subsamples and not a function of covariates. The hazard of each group $\lambda_{i}(t)$ is assumed to be a certain proportion of the baseline hazard which is expressed as:

$$
\frac{\lambda_{i}(t)}{\lambda_{0}(t)}=\exp \left(\beta^{\prime} x_{i}\right)
$$

Or equivalently as:

$$
\log \lambda_{i}(t)=\log \lambda_{0}(t)+\beta^{\prime} x_{i}
$$

The coefficients can be expressed as hazard ratios in which case a value of $\beta=1$ represents a covariate that does not affect the hazard rate. A coefficient greater than one implies that an increase in that variable raises the risk of exit while a coefficient less than one implies that an increase in that variable reduces the risk of exit or prolongs survival time ${ }^{4}$.

The proportional hazard model discussed so far is ideal for durations that are observed in continuous-time. However, in most cases we only know the interval during which transition between states has occurred but not the exact moment of transition for each individual. Such observations are said to be grouped-durations (although the underlying process may still be

\footnotetext{
${ }^{4}$ In applications where the actual regression coefficients are reported, a covariate with a negative (positive) coefficient reduces (increases) the risk of exit.
} 
continuous) and the hazard within an interval is assumed to be constant. Such data are better analyzed with Discrete-time proportional hazard models (Cameron and Trivedi, 2005).

The establishment panel data used in this paper contains grouped-durations since the census is carried out annually. The results presented in sections 5 and 6 are therefore based on variants of a discrete-time hazard model shown in equation (7). The discrete-time hazard function is defined as the probability of transition at discrete time $t_{j}, j=1,2, \ldots$, given survival to time $t_{j}$ :

$$
\lambda\left(t_{a} \mid x\right)=\operatorname{Pr}\left[t_{a-1} \leq T<t_{a} \mid T \geq t_{a-1}, x\left(t_{a-1}\right)\right], \mathrm{a}=1,2 \ldots \mathrm{A} .
$$

The corresponding discrete-time survivor function is obtained from the discrete-time hazard function in a recursive manner as:

$$
\begin{aligned}
S\left(t_{a} \mid x\right) & =\operatorname{Pr}\left[T \geq t_{a-1} \mid x\right] \\
& =\prod_{s=1}^{a-1}\left(1-\lambda\left(t_{s} \mid x\left(t_{s}\right)\right)\right)
\end{aligned}
$$

\section{(b) Choice of Covariates}

Drawing on the discussion in sections 2 and 3(a), equation (7) will be estimated based on the following covariates:

$\lambda_{i}=f($ size,duration,productivity,factor intensity,ownership,industry characteristics, location $)$ Establishment size is measured by the number of employees while duration dependence will be measured by establishment age. However, because of the cut-off point in the census and the existence of multi-unit firms, some establishments are much older than others by the time they first appear in the dataset. For this reason experiments are also carried out using duration since an establishment's first appearance in the dataset in addition to age. 
Establishment level productivity is calculated based on industry specific production functions rather than using a single equation for all industries (with industry dummies) as in existing studies on African firms. A well known problem with estimation of production functions is the correlation between input levels and unobserved productivity that renders OLS estimators of factor elasticities biased and inconsistent. An innovative solution to this problem has been suggested by Olley and Pakes (1996) using firm level investment as a proxy for unobserved productivity. Levinsohn and Petrin (2003) developed this approach further in which a variety of intermediate inputs can be used as proxies for productivity with the extra advantage of overcoming the discontinuity problem in the investment proxy. The means intermediate inputs are easier to adjust than capital in response to productivity shocks. Both approaches follow a two-stage procedure in which the first stage provides consistent estimates for variable inputs and the second stage identifies the coefficient on capital. Ackerberg et al. (2005) criticized this approach by arguing that the first stage estimation especially in the case of Levinsohn and Petrin (2003) does not provide consistent estimates for variable inputs because of high collinearity and hence the whole procedure fails to resolve the endogeneity problem. Ackerberg et al. (2005) proposed an alternative approach which also has two-steps but does not require identification of variable inputs coefficients in the first stage ${ }^{5}$.

The current paper however uses the system GMM estimator, which has been developed in parallel with the proxy variables approach, to estimate value added production functions for nine industries. This estimator resolves the endogeneity problem by using instrumental variables whereby first differences are instruments for input levels and lagged levels are

\footnotetext{
5 The productivity measure in Frazer (2005) is derived from a value added production function estimated using this procedure. Söderbom et al. (2006) did not estimate a production function but rather used value added per worker as a measure of productivity.
} 
instruments for first differences ( Blundell and Bond, 1998). Unlike the proxy variable approaches, the systems GMM estimator has the advantage of allowing for firm fixed effects ${ }^{6}$. The industry level production function is given by:

$y_{i t}=\beta_{0}+\beta_{y} y_{i t-1}+\beta_{k} k_{i t}+\beta_{l} l_{i t}+u_{i t}$

$u_{i t}=\eta_{i}+w_{i t}+v_{i t}$

Where $y_{i t}, k_{i t}$ and $l_{i t}$ are logarithms of value $\operatorname{added}^{7}$, capital and labor in establishment $i$ in year $t$ and $\beta_{y}, \beta_{k}$ and $\beta_{l}$ are their respective coefficients. The composite error term $u_{i t}$ comprises $\eta_{i}$ which is a time invariant establishment specific effect, $w_{i t}$ which represents establishment level productivity and $v_{i t}$ which represents disturbances that are neither correlated with inputs nor with each other over time. It is assumed that $\eta_{i}$ is correlated with the levels of capital and labor inputs. The productivity term is assumed to follow a first-order autoregressive process, i.e. $w_{i t}=\rho w_{i t-1}+\xi_{i t}$. The model allows $w_{i t}$ to be correlated with inputs but the innovation in $w_{i t}$, i.e., $\xi_{i t}$ is uncorrelated with input choice. Estimation of (9) on first-differenced variables removes the correlation of the fixed effect with capital and labor inputs. However, the presence of the lagged dependent variable in the right side of the equation means that lagged differences will be correlated with the first-differenced error term making the usual fixed and random effects panel data estimators unsuitable for estimation of dynamic models $^{8}$. The simple first-difference GMM estimator suggested by Arellano and Bond (1991) overcomes this problem by using suitably lagged levels as instruments for first differences. However, the Arellano and Bond (1991) estimator is shown to have undesirable small sample properties in terms of bias and inefficiency because of weak instruments. Blundell and Bond (1998) developed a system GMM estimator that minimizes this problem

\footnotetext{
${ }^{6}$ See for instance the comparisons of these methods in Ackerberg et al. (2005)

${ }^{7}$ Value added is calculated by subtracting the value of intermediate inputs from total value of production.

${ }^{8}$ For instance. $y_{i t-1}-y_{i t-2}$ will be correlated with $v_{i t}-v_{i t-1}$ through $v_{i t-1}$ even when $v_{i t}$ are not be autocorrelated. In this case $y_{i t-2}$ qualifies as a valid instrument because it is not correlated with $v_{i t}-v_{i t-1}$.
} 
by adding a regression in levels whereby lagged differences are used as instruments for variables in levels. The instruments for the equations in first-differences include lagged levels by at least two periods while for the levels equation the instruments include all lagged firstdifferences.

The production function coefficients based on the Blundell and Bond (1998) system GMM estimator are provided in Appendix Table 2. The table also reports the p-values of the Hansen test for overidentification and it shows that the instruments are not correlated with the equation errors for each industry. Firm level productivity measures are calculated as residuals from these production functions. Since monetary values of output and input are deflated by firm specific price indices, the productivity measures are not tainted by differences in markup pricing (see section 4 for details). Notwithstanding the critique by Ackerberg et al.(2005) on the method suggested by Levinsohn and Petrin (2003), the survival analysis in section 5 uses productivity measures derived from both the system GMM and LP estimators to check the sensitivity of the productivity effect to differences in the production function estimation method.

The hazard model also includes two indictors of factor intensity. The first is capital intensity measured as real capital stock (in local currency) per employee. The second is skill intensity proxied by the ratio of an establishment's average real wage (i.e. real wage bill in local currency divided by the number of employees in an establishment) to the industry average real wage. The idea is that other things being equal, hiring more skilled workers would push an establishment's average wage above the industry mean.

The structure of ownership is represented by a set of dummy variables. In this paper, an establishment is considered to be female-owned if women account for at least one-third of the 
number of owners. This distinction is based on the number of entrepreneurs rather than their contribution to equity. However, since $75 \%$ of female-owned establishments have a single owner, the distinction is unlikely to make a big difference. The criterion is somewhat different for foreign ownership. Establishments with non-zero foreign direct investment will be considered as foreign-owned. Finally, establishments which belong to a multi-unit firm are also identified by a dummy variable that takes the value one for such firms and zero for single-unit establishments.

As indicated earlier, certain aspects of the exit hazard are shared equally by all producers in an industry while varying across industries. For instance, not all industries face the same rate of change in demand over time. The effect of such business cycles on survival will be captured by annual growth rates of real output at the industry level. Another variable of interest is the degree of exposure to competition from imports. To account for this, import penetration rates are calculated for each industry by merging import values obtained from the Ethiopian Customs Authority with values of domestic production from the CSA's annual manufacturing census. In some industries rivalry between domestic firms could be the main source of competition. Following the practice in industrial economics, the intensity of such domestic competition is measured through the Herfindahl Concentration Index. This index is simply the sum of the squared market share of each establishment in an industry ${ }^{9}$. The closer the index gets to zero the higher is the degree of competition and the closer it gets to one it indicates monopoly.

Entry barriers are also likely to vary across industries and the heftier they are the lower is the expected rate of entry which in turn attenuates the degree of competition for incumbents.

\footnotetext{
${ }^{9}$ Although the sample excludes state-owned enterprises, the market shares and the Herfindahl index are calculated taking into account all firms - both public and private.
} 
Since direct measures of entry barriers are not available, we approximate those by the observed rate of entry, i.e., the ratio of the number of entrants to the total number of establishments in an industry. Similarly, the process of exit may not go smoothly in all industries. The theoretical literature on exit decisions (Ericson and Pakes, 1995) is built around firms' assessment of the present value of expected profits against the current value of fixed assets in a second-hand market. The existence of second-hand markets is therefore assumed although it is not very crucial for the theory. Such markets might be thin or missing for some industries in developing countries. The scope of the second-hand market for machinery and equipment is therefore our proxy for exit barriers assuming such markets would facilitate the process of exit by allowing firms to recover at least part of their fixed assets. The proxy is a dummy variable that takes the value one if more than $10 \%$ of the establishments in an industry participate in the second hand market. It is quite possible that thriving second hand markets may reduce the risk of exit. If the investment climate is very uncertain, the possibility to reverse investment decisions could increase entrepreneurs' propensity to invest which in turn improves firm survival.

Finally the variation of exit risk across space will be captured by a location dummy. This dummy variable identify firms located in the capital city Addis Ababa allowing us to examine whether better transport and financial infrastructure in the capital city enhance the probability of survival. 


\section{Data ANd Descriptive Statistics}

This paper uses establishment level panel data for the period 1996 to 2002 . The panel is based on the annual census of manufacturing carried out by the Central Statistics Authority (CSA) of Ethiopia. The census covers all establishments that employ at least 10 persons. Each establishment is identified by a unique ID number in combination with region and 4digit Standard Industrial Classification (SIC) codes. The total number of establishments increases from 608 in 1996 to 823 in $2006 .{ }^{10}$ The analysis in this paper focuses only on privately-owned manufacturing firms whose number increases from 471 in 1996 to 686 in 2002.

The data contain all relevant information for productivity and survival analysis. Establishment level prices for the main product are used to construct establishment specific price indices using 1996 as the base year. Output and input values are deflated by the establishment level price indices so that unobserved variation in mark-up pricing does not undermine productivity measurements, a common problem in productivity analysis (Tybout, 2000). A new series on capital stock has been generated using the perpetual inventory method $^{11}$. Table 1 provides summary statistics for the variables of interest both at the industry and sectoral levels while Table 2 gives the average characteristics of surviving and exiting firms. Time trends of variables are summarized in Appendix Table $2^{12}$.

\footnotetext{
${ }^{10}$ The annual average exit rate for public-owned enterprises, excluding privatized firms, is about $3 \%$ as compared to a $16 \%$ for privately-owned firms.

${ }^{11}$ Further details on the construction of establishment specific price indices are provided in Shiferaw (2007) and see Shiferaw (2006) for details on the construction of a new series on capital stock.

${ }^{12}$ Although some of the variables are in logarithms in the estimated duration models, the summary statistics in this section are not in logs to facilitate a straightforward description of private sector manufacturing in Ethiopia.
} 
The rate of entry (exit) is defined as the ratio of the number of entrants (exiting establishments) to the total number of establishments in an industry in a given year. About $16 \%$ of privately-owned firms on average exit the manufacturing sector every year while $20 \%$ join the sector ${ }^{13}$. Industries with rapid rates of exit are also those with high rates of entry. The metal and light machineries industry, for instance, exhibits the highest exit rate at $24 \%$ followed by the wood and furniture industry at $19 \%$. However, because of the cut-off point in the census, it is difficult to isolate establishments that recently crossed the 10 -employees threshold from new establishments that joined an industry for the first time. Neither does the data distinguish establishments that have closed down from those that have slipped below the cut-off point or those that switched to another industry within manufacturing or to other sectors outside of manufacturing. Therefore, establishment turnover rates will tend to be overstated.

\section{[Insert Table 1 Here]}

Table 2 shows that exiting establishments are on average less than half the size of survivors. Across industries, the average size of privately-owned establishments in Ethiopian manufacturing has been increasing modestly during the sample period (Appendix Table 2) although it should be noted that for the manufacturing sector as a whole, the average establishment size has been declining due to downsizing of large public enterprises. Figure 1 plots the survivor functions for small (with less than 30 employees), medium (30 to 100 employees) and large (more than 100 employees) establishments. The upper, middle and lower lines correspond to the survivor functions for large, medium and small establishments,

\footnotetext{
${ }^{13}$ World Bank (2005) documents comparable rates of turnover for other developing countries.
} 
respectively, showing a positive association between size and survival. For large establishments, the slope of the survivor function is essentially flat at any point in time while it declines with establishment age particularly for small producers. This indicates that the risk of exit is conditional on survival time for small and medium size establishments but not so for large establishments.

\section{[Insert Figure 1 Here]}

There is wide variation in capital intensity across industries whereby the wood and furniture industry is the least capital intensive and the chemical and leather and footwear industries are the most capital intensive. The capital intensity of private sector manufacturing has more than doubled over the 1996 to 2002 period. Both capital and skill intensity tend to be positively associated with better chances of survival. According to Table 2, exiting private establishments are on average less capital intensive (about $60 \%$ ) than survivors. While the average wage in the private sector is below the industry average (which also includes stateowned firms) surviving private establishments are much closer to the industry average than exiting establishments. Table 2 also shows that total factor productivity is slightly above the industry average for surviving establishments while for exiting establishments it is below the industry average.

\section{[Insert Table 2 Here]}

Table 1 also provides some information on the structure of ownership. About $18 \%$ of the establishments in this sample belong to multi-unit firms while the rest are single-unit establishments. Table 2 shows that the fraction of multi-unit firms among surviving 
establishments is more than twice the fraction among exiting establishments. The unconditional rate of exit among single-unit establishments is $18 \%$ which is three times the exit rate among establishments that belong to multi-unit firms. Along gender lines, about onethird of private establishments are owned by women according to our definition of femaleownership. Women are also playing a growing role in Ethiopian manufacturing with the fraction of female-owned establishments rising from $27 \%$ in 1996 to about $35 \%$ in 2002 . The proportion of female-owned establishments is $38 \%$ among survivors and $24 \%$ among exiting establishments suggesting that female-ownership is associated with better chances of survival. Supporting the same point, the observed rates of exit for female- and male-owned establishments are $12 \%$ and $18 \%$, respectively. Only $5 \%$ of private establishments have a non-zero FDI with no significant change over the sample period. According to Table 2, about $5 \%$ of surviving establishments have some FDI as compared to $2 \%$ among those that closed down. The exit rate for establishments with no FDI is $14 \%$ as compared to $6 \%$ among establishments with some FDI. This preliminary analysis suggests that female-ownership and belonging to a multi-unit or multinational firm tend to reduce the risk of exit.

About $66 \%$ of all private sector manufacturing establishments are located in and around the capital city, Addis Ababa. The city hosts more than $80 \%$ of the establishments in some industries such as leather, printing and chemical. This concentration has been waning gradually as other major cities become important industrial centers. Location also seems to matter for survival. The capital city accounts for about $60 \%$ of exiting establishments while is hosts $67 \%$ of the survivors. The average rates of exit among establishments located in the capital city is $14.5 \%$ which compares favorably with the $18 \%$ exit rate in other locations. 
All industries have experienced output growth and the manufacturing sector as a whole expanded by about $10 \%$ per annum during the sample period. Fast growing industries include the chemical, metal and leather industries with annual average growth rates of $18 \%, 15 \%$ and $13 \%$, respectively. The degree of exposure to import competition varies across industries with some industries such as the chemical, light machineries and wood industries apparently bearing the brunt of it. Nonetheless, it is interesting to see that these are the same industries that exhibited rapid output growth during the sample period. The average Herfindahl index for the Ethiopian manufacturing sector is 0.05 which suggests that the sector is dominated by small producers each with insignificant market share. Across industries, market concentration is very low in the food and textile industries while the non-metal industry shows the highest degree of concentration.

\section{Results of Discrete Time Hazard Models}

Table 3 reports hazard ratios based on four different specifications of the discrete-time proportion hazard model. Columns 2 and 3 show the coefficients from a simple model that includes only establishment level characteristics while columns 4 and 5 report the results from an extended model that includes industry characteristics. Both the simple and extended versions include productivity measures calculated from production functions using the Blundell and Bond (1998) system GMM estimator and the Levinsohn and Petrin (2003) estimator. Once again, a hazard ratio that is less (greater) than 1 implies a decrease (increase) in the risk of exit associated with that variable.

The first and perhaps familiar observation is that the risk of exit decreases substantially with establishment size. Like in other studies, small establishments in Ethiopian manufacturing are 
more likely to exit the market than large establishments. The relationship between size and survival appears to be non-linear as indicated by the coefficient on the quadratic term which is greater than one and statistically significant. Most importantly, the results in Table 3 indicate that productivity reduces the probability of exit. The coefficient on the productivity measure derived from the system GMM estimator is less than one and statistically significant at $10 \%$ after we control for industry effects while the productivity term from the Levinsohn-Petrin estimator is highly significant in all specifications. Despite differences in the size and significance of the coefficients on productivity, the results reveal the existence of competitive markets that weed away less efficient producers from the manufacturing sector. The relevance of size and productivity for firm survival in Ethiopia manufacturing is thus consistent with theories of market selection and with the findings of Frazer (2005) and Söderbom et al. (2006) for other African countries.

\section{[Insert Table 3 Here]}

The hazard ratio corresponding to establishment age is less than one and statistically significant indicating that the hazard rate exhibits negative duration dependence. This implies that recent entrants are more likely to exit but the hazard declines over time for survivors. Since the model controls for establishment size and productivity, the negative duration dependence points to other survival skills that may take time to build, such as networking and the capability to diversify by introducing new and better products.

The choice of technology as captured by factor proportions also influences the survival of establishments in this sample. The coefficient on capital intensity, although close to one, is statistically significant implying that capital intensive establishments seem to have better chances of 
survival than labor intensive ones. Skill intensity on the other hand is not significantly associated with survival probabilities especially once industry characteristics are taken into account.

As discussed earlier, nearly a quarter of private establishments in Ethiopian manufacturing belong to multi-unit firms and contribute significantly to aggregate output and employment. The hazard ratio corresponding to the dummy variable indicating affiliation to a multi-unit firm reveals that the risk of exit declines by about $50 \%$ to $60 \%$ of the hazard facing single-unit establishments. Similar results were reported for UK manufacturing firms in Disney et al. (2003). As firms grow through branching out, it seems that survival skills and other relevant knowledge are passed on to the new establishments. The cost of learning for such establishments is therefore expected to be much lower than that for single-unit entrants. This finding could also mean that given credit market constraints, establishments under a multi-unit firm can ride over negative business shocks by sharing financial resources among themselves which is not possible for single-unit establishments. In both instances expansion through branching out seems to be a response to an uncertain business environment.

This observation is consistent with research findings on investment behavior of African manufacturing firms. Several studies show that more than $50 \%$ of African firms have zero investment at any point in time and the rate of investment (i.e. the investment to capital ratio) is very low despite exceptionally high profit rates (Bigsten et al., 1999). Investment also tends to be bulky and intermittent, a pattern consistent with uncertain investment climates (Bigsten et al., 2005; Shiferaw, 2006). The key point is that entrepreneurs tend to respond to uncertainty by opening new businesses rather than ploughing back their profits to enlarge an existing establishment, and this paper shows that such a strategy indeed reduces the risk of exit ${ }^{14}$. However, these developments

\footnotetext{
${ }^{14}$ Fafchamps $(1997,2004)$ makes similar remarks about Africa firms.
} 
could compromise scale economies, capital accumulation and innovation - activities that are strongly associated with establishment size and are very crucial for industrial success.

The presence of foreign capital has the expected sign in the sense that it tends to reduce the hazard of exit but the coefficient is not statistically significant. This has to do mainly with the very small proportion (less than 5\%) of establishments with foreign direct investment.

Interestingly, we find that female-owned establishments in Ethiopian manufacturing are more likely to survive as compared to male-owned establishments. The coefficient on the gender dummy suggests that the risk of exit among female-owned establishments is about three quarters of that of male-owned establishments. This differs markedly from McPherson (1995) where in two of the four countries that he studied (Swaziland and Botswana) there were no gender differences in the probability of exit while in the other two countries (Malawi and Zimbabwe) women proprietors were at a disadvantage. The fact that women account for about one third of privately-owned manufacturing establishments in this sample, most of which are in the small and medium size categories, suggests that women still face higher, albeit gradually declining, entry barriers as compared to male entrepreneurs. Similarly, while the average size of male-owned establishments grew by about $9 \%$ per annum during the sample period, the rate of growth for female-owned establishments was about $4 \%$. The literature on female entrepreneurs points that these are often related to lack of education, experience and poor access to financial resources. However, the results in Table 3 suggest that once female-owners enter the market, they are better at staving off business closure. The Ethiopian manufacturing census does not collect data on entrepreneur characteristics which would have clarified whether such positive outcomes are due to better managerial skills and access to resources. This seems very unlikely to be the case given the prevailing gender disparity in literacy and school enrolment rates in Ethiopia. However, the 2002 Ethiopian firm level survey 
carried out by the World Bank shows that female managers who are also the sole proprietors or majority share holders are more likely to have college level of education as compared to their male counterparts $^{15}$. However, these female managers have little experience (about 2 years) in manufacturing before starting to run the current firm as compared to men who have eight to nine years of experience. This supplementary information from the World Bank data suggests that the female advantage in firm survival is unlikely to be the result of more human capital among female owners/managers.

While further research is needed to shed more light on this matter, well documented factors such as gender based discrimination in the labor market could play a role by undermining the attractiveness of wage employment for women as an alternative to running their own business or to selfemployment (Loscocco et al., 1991; Hisrich and Brush, 1984). Women would therefore be extra cautious in making business decisions, a view supported by micro-finance and cash transfer programs that prefer to target women ${ }^{16}$. The slow growth observed among female owned establishments could also reflect among other things the time constraint that household responsibilities impose on women's ability to expand an establishment.

Columns 4 and 5 of Table 3 expand the model by including industry specific covariates. In addition to the potentially time-varying industry level covariates, this version of the hazard model includes industry dummies (coefficients not reported here) to control for industry fixed effects and a likelihood ratio test rejects the exclusion of the industry dummies. While the overall performance of

\footnotetext{
${ }^{15}$ Female and male adult literacy rates are $32.4 \%$ and $48.1 \%$, respectively while combined enrollment rates are $27 \%$ and 41\%, respectively (UNDP, 2003). The 2002 World Bank firm level survey was conducted in collaboration with government and non-government agencies. The survey captures establishments mainly but not exclusively in the manufacturing sector and includes micro enterprises as well.

${ }^{16}$ The coefficient on the gender dummy may also suffer from a selection bias if unobserved entry barriers to the manufacturing sector are higher than in other sectors such as services. In that case, the gender effect is likely to be exaggerated since only women with superior entrepreneurial skills would be able to break into the manufacturing sector.
} 
the model has improved due to the inclusion of industry effects, the results in columns 4 and 5 are comparable to those in columns 2 and 3. If anything, the size and significance of coefficients on firm specific variables in columns 4 and 5 are now much more similar than in the case of the restricted models in columns 2 and 3. The results suggest that the probability of survival is higher among larger, older, capital intensive and efficient establishments and it improves further with femaleownership and affiliation with a multi-unit firm. The discussion in the next few paragraphs will therefore focus only on the coefficients of industry characteristics.

One would normally expect exit rates to rise during a recession. In that sense it is intriguing to find that in the Ethiopian context output growth at the industry level is associated with a higher risk of exit at the micro-level. Although the coefficient is statistically significantly, for all practical purposes it is not different from one - implying that it does not increase the risk of exit noticeably . At best this finding suggests that markets are competitive and there is no respite for less efficient establishments even during periods of industry expansion. In this sample the variance of entry rate across industries is greater than its variance across time for individual industries. The coefficient on entry rate is less than one and highly significant indicating that industries with low entry barriers tend to have low exit rates as well. If entrants truly challenge incumbents for market share, one would rather expect higher entry rates to increase the exit hazard. Nonetheless, even for developed countries, Geroski (1995) observed that entrants do not pose a significant threat to incumbents and concluded that entry is generally a poor substitute for active competition among incumbents in a given market.

The coefficient on the Herfindahl index, measuring the degree of domestic competition, is greater than one and statistically significant. This means an increase in market concentration increases firm exit rate. While this looks counter intuitive, a closer look at the data reveals why this could be possible. Given the maximum possible value for the Herfindahl index (i.e. 1), the distribution of the 
index in Ethiopian manufacturing is skewed to the right with a mean of 0.05 and a maximum value of 0.43 . This means that the Ethiopian manufacturing sector is dominated by small establishments each with a very small market share (the average market share is $1.25 \%$ ). In this case, an increase in the Herfindahl index, within the stated range, points to a market structure in which a few large firms begin to break away from other competitors with a relatively large margin. The rest of the establishments will have to compete intensively for the remaining market share.

The results in Table 3 also suggest that competition from imports does not raise the risk of exit. The presence of second-hand markets for machinery tends to reduce the risk of exit although the coefficient is only marginally significant. It could mean that the positive effect of second hand markets on firm survival through higher rates of investment is more dominant than their effect on reducing exit barrier. To sum up, the results the survival analysis suggest that while the firm level attributes of longevity in African manufacturing are very similar to those in developed countries, the same cannot be said about industries level effects. Further research is needed on the industry level characteristics.

\section{Sensitivity Analysis}

It is reasonable to expect that the hazard models discussed so far may suffer from incomplete specification. For linear models, unobserved heterogeneity leads to biased estimates if the omitted variables are correlated with explanatory variables. For duration models however unobservables undermine the identification of hazard parameters as well as duration dependence even when they are not correlated with covariates. For instance, a negative duration dependence could be observed in a given sample if firms with high unobserved probabilities of exit leave the market first, leaving behind a group of firms that are very likely to stay longer (Cameron and Trivedi, 2005). Such duration dependence resulting from 
unobserved heterogeneity is difficult to distinguish for true negative duration dependence whereby the risk of exit declines over time for all firms. A careful analysis of hazard rates should therefore take into account the effect of unobservables.

Several approaches have been proposed in the literature to incorporate unobserved heterogeneity in duration models since the early work by Elbers and Ridder (1982). The standard practice is to assume that unobservables are multiplicative and independently distributed with well know functional forms such as the Gamma or log-normal distributions. However, Heckman and Singer (1984) demonstrate, both in theory and empirically, that structural parameters of duration models are very sensitive to the choice of a functional form for unobservables. Instead of an ad hoc choice of distribution functions, they proposed a consistent non-parametric maximum likelihood estimator in a general class of proportional hazard models with censored durations and time varying covariates (Heckman and Singer, 1984). In this section we follow the Heckman-Singer procedure to re-estimate the discretetime proportional hazard model with unobserved heterogeneity.

\section{[Insert Table 4 Here]}

Table 4 reports the coefficients based on a discrete mixing distribution in accordance with the Heckman-Singer proposition. The results in column 2 use establishment age to capture the nature of duration dependence while column 3 uses the number of years since an establishment is first observed in the sample. Due to the cut-off point in the census and the difficulty to establish the date of entry for establishments that belong to multi-unit firms, some entrants are much older than others by the time they appear for the first time in the census. To detect the sensitivity of results to this situation we use both establishment age and 
time since an establishment is first observed in the data. Both columns in Table 4 use the productivity measures calculated from the system GMM estimator.

Aside from few exceptions, the qualitative patterns of survival documented in the previous section are still recognizable in the revised estimates in Table 4. The coefficient on age is not statistically significance any longer but a negative duration dependence is still evident when we use time since an establishment is first observed in the sample instead of age. Once unobserved heterogeneity is taken into account, relative efficiency turns out to be highly significant in reducing the probability of exit. The same is true for the effect of establishment size which has a non-linear but positive impact on survival time. Capital and skill intensity are however either weakly significant or insignificant depending on the specification with a general tendency toward reducing the risk of exit. It is important to note that the significance of ownership structure for establishment survival reported in Table 3 is not driven by unobserved heterogeneity. The revised estimates in Table 4 confirm that female ownership enhances the likelihood of survival while single-unit establishments are more likely to exit as compared to establishments that belong to a multi-unit firm. While FDI seems to lower the hazard rate, its effect is still imprecise as in the previous set of results.

Similar conclusions can be drawn about industry specific effects. Industry growth, entry rate and the presence of second hand markets remain to be significant. A clear difference is the coefficient on the Herfindahl index which is now statistically insignificant while import penetration has a significant albeit small effect toward increasing the risk of exit as reported in column 3. For the same sample, Shiferaw (2007) shows that the tolerance of inefficient firms tends to decline with the degree of exposure to international competition. As in Table 3, 
there is no evidence that the choice of location affects survival time in Ethiopian manufacturing.

\section{Conclusions}

The paper takes into account establishment and industry level characteristics to understand the probability of exit among privately-owned Ethiopian manufacturing establishments. While the manufacturing sector is still at an incipient stage of development, the manner in which producers are selected into the sector is very similar to what is observed in mature market economies. Large establishments are more likely to survive than smaller businesses similar to what is observed in developed and a few other African countries. The fact that surviving establishments face hazard rates that decline over time reveals that firms learn survival skills by staying in the market. Improving firm level productivity also significantly reduces the risk of exit confirming that there is an underlying process of market selection that eliminates inefficient producers.

It has been observed that belonging to a multi-unit firm significantly prolongs survival time of individual establishments. This suggests that business skills are passed on from parent to new establishments in the group cutting significantly the cost and time of learning essential business skills. This finding could also reflect the possibility that such establishments overcome unfavorable business shocks by transferring financial resources among themselves. While risk sharing among establishments in a multi-unit firm may improve their likelihood of survival, it does not necessarily imply better performance at the industry or sectoral level. Capital adjustment patterns in African manufacturing firms reveal an investment behavior that

is consistent with the presence of uncertainty and irreversibility. If irreversibility of 
investment projects in an uncertain investment climate induces entrepreneurs to prefer opening another small business instead of ploughing back their profits to enlarge a single establishment, there would be very slow transition from small to medium and large firm size categories. The sector at large would thus fail to benefit from scale economies and innovation if average firm size remains too small. Historically, economies of scale and innovation have played a centre role in the industrial success of advanced and newly industrializing countries. Given these indications on the role of uncertainty on firm behavior, further research is needed to identify the major sources of uncertainty and how to tackle them. At least in the Ethiopian context the fragile political process and lack of cooperation and thrust between the private and public sectors are obvious areas for improvement since the macroeconomic indicators were by and large stable during the sample period.

The growth in private sector participation in Ethiopian manufacturing has been accompanied by rising female ownership and the hazard estimates show that women entrepreneurs are better at staving off firm closure as compared to their male counterparts. While further analysis is needed to understand the personal characteristics of women entrepreneurs, the gender disparities in literacy and enrolment rates at the national level as well as recent evidence on establishment surveys by the World Bank suggest that the observed positive performance is not due to superior human capital of women entrepreneurs in Ethiopia. The fact that female-ownership is prevalent among smaller establishments with a relatively slow rate of growth point to the difficulties that female entrepreneurs continue to face. This makes their achievement in terms of survival even more remarkable and suggests that business support services that target women entrepreneurs may have better chances of furthering this success story which at the moment could derive from extra caution in their business decisions. 


\section{$\underline{\text { References }}$}

Ackerberg, D., Caves,K., \& Frazer, G. (2005). “ Structural Identification of Production Functions,” Unpublished Manuscript, Department of Economics, University of Arizona.

Audretsch, D., \& Mahmood,T. (1994). "The Rate of Hazard Confronting New Firms and Plants in US Manufacturing," Review of Industrial Manufacturing 9 (1), 41 - 56.

Arellano, M., \& Bond, S. (1991). "Some Tests of Specification for Panel Data: Monte Carlo Evidence and an Application to Employment Equations." Review of Economic Studies 58, 277-297.

Balassa, B. (1988). "Interest of Developing Countries in the Uruguay Round." The World Economy 11 (1), 39-54.

Bartelsman, E., Scarpetta,S., \& Schivardi, F. (2003). “ Comparative Analysis of Firm Demographics and Survival: Micro-level Evidence for the OECD Countries." Economics Department Working Papers, No.348. Paris: OECD.

Bernard, A. B., \& Jensen, J.B. (2007). "Firm Structure, Multinationals and Manufacturing Plant Deaths," Review of Economics and Statistics 84 (2), 193-204.

Bernard, A. B., Jonathan E., Bradford J., Samuel, K. (2002). "Plants and Productivity in International Trade," American Economic Review 93 (4),1268-90. 
Biggs, T., Shah, M., \& Srivastava, P. (1995). “ Technological Capabilities and Learning in African Manufacturing.” World Bank Technical Paper 288. Washington D.C., World Bank.

Bigsten, A., Collier, P., Dercon, S., Fafchamps, M., Gauthier, B., Gunning, J.W., Oostendorp, R., Pattillo, C., Söderbom, M., \& Teal, F. (2005). “Adjustment Costs and Irreversibility as Determinants of Investment: Evidence from African Manufacturing." The B.E. Journals in Economic Analysis and Policy 4 (1), 1-29.

Bigsten, A., Collier,P., Dercon, S., Fafchamps, M., Gauthier, B., Gunning, J.W., Isaksson, A., Oduro, A., Oostendorp, R., Pattillo, C., Söderbom, M., Sylvain, M., Teal, F., \& Zeufack, A. (1999). "Investment in Africa's Manufacturing Sector: A Four Country Panel Data Analysis.” Oxford Bulletin of Economics and Statistics 61(4), 489-512.

Blundell, R., \& Bond, S. (1998). "Initial conditions and moment restrictions in dynamic panel data models," Journal of Econometrics 87(1), 115-143.

Cameron, A. C., \& Trivedi, P.K. (2005). Microeconometrics: Methods and Applications. New York: Cambridge University Press.

Caves, R.E., \& Porter, M.E. (1977). “ From Entry Barriers to Mobility Barriers: Conjectural Decisions and Contrived Deterrence to New Competition.” Quarterly Journal of Economics $91(2), 241-262$.

Collier, P., \& Gunning, J.W. (1999). “Explaining African Economic Performance,” Journal of Economic Literature 37 (1), 64-111. 
Cox, D.R. (1972). “ Regression Models and Life Tables”, Journal of the Royal Statistical Society $34(2), 187-202$.

Diseny, R., Haskel, J., \& Heden, Y. ( 2003). "Entry, Exit and Establishment Survival in UK Manufacturing," Journal of Industrial Economics 51( 1), 91-112.

Dunne, T., Roberts, M.J., \& Samuelson, L. (1989). "The Growth and Failure of U.S. Manufacturing Plants," Quarterly Journal of Economics 104 (4), 671-698.

Dunne, P., \& Hughes, A. (1994). “Age, Size, Growth and Survival: UK Companies in the 1980s", Journal of Industrial Economics 42 ( 2), 115-140.

Elbers, C., \& Ridder, G. (1982). “True and Spurious Duration Dependence: The Identifiability of the Proportional Hazard Model," Review of Economic Studies 49 (3), 403-409.

Ericson, R., \& Pakes, A. (1995). “ Markov-Perfect Industry Dynamics: A Framework for Empirical Work," Review of Economic Studies 62 (1), 53-82.

Fafchamps, M. (1997). "Introduction: Markets in Sub-Saharan Africa.” World Development $25(5), 733-734$.

Fafchamps, M. (2004). Market Institutions in Sub-Saharan Africa: Theory and Evidence. Massachusetts: MIT Press. 
Frazer, G. (2005). 'Which Firms Die? A Look at Manufacturing Firm Exit in Ghana.' Economic Development and Cultural Change 53 (3), 585-617.

Geroski, P. (1995). "What do we Know about Entry?” International Journal of Industrial Organization 13 (4),421-440.

Heckman, J.J., \& Singer, B. (1984). "A Method for Minimizing the Impact of Distributional Assumptions in Econometric Models of Duration Data," Econometrica 52 (2), 271-320.

Hisrich, R.D., \& Brush, C.G. (1984). “ The Women Entrepreneur: Management Skills and Business Problems.” Journal of Small Business Management 22 (1), 30-37.

Hopenhayn, H. (1992). “ Entry, Exit and Firm Dynamics in Long Run Equilibrium.” Econometrica 60 (5),1127-1150.

Jovanovic, B. (1982). "Selection and the Evolution of Industry." Econometrica 50 (3), 649670.

Liedholm C., \& Mead, D.C. (1999). Small Enterprises and Economic Development. London: Routledge.

Levinsohn, J., \& Petrin, A. (2003). "Estimating Production Functions Using Inputs to Control for Unobservables." Review of Economic Studies 70 (2), 317-341. 
Liedholm, C., McPherson, M., \& Chuta, E. (1994). “Small Enterprises Employment Growth in Rural Africa." American Journal of Agricultural Economics 76 (5), 1177-1182.

Little, I., Mazumdar, D., \& Page, J.M. (1987). Small Manufacturing Enterprises: A Comparative Analysis of Indian and Other Economies. NY: Oxford University Press.

Loscocco, K.A., Robinson, J., Hall, R.H., Allen, J.K. (1991). “ Gender and Small Business Success: An Inquiry into Women's Relative Disadvantage.” Social Forum 70 (1), 65-85.

McPherson, M. A. (1995). “ The Hazard of Small Firms in Southern Africa," Journal of Development Studies 32 (1), 31-54.

Mead, D.C., \& Liedholm, C. 1998. “ The Dynamics of Micro and Small Enterprises in Developing Countries.” World Development 26 (1), 61-74.

Mengistae, T. (2006). “ Competition and Entrepreneurs' Human Capital in Small Business Longevity and Growth.” Journal of Development Studies 42 (5), 812-836.

Olley, S., \& Pakes, A. (1996). “ The Dynamics of Productivity in the Telecommunications Equipment Industry,” Econometrica 64 ( 6), 1263-97.

Pakes, A. \& Ericson, R. (1998). "Empirical Implications of Alternative Models of Firm Dynamics, " Journal of Economic Theory 79 ( 1), 1-46.

Porter, M.E. (1990). The Competitive Advantage of Nations. London: Macmillan. 
Shiferaw, A. (2007). "Firm Heterogeneity and Market Selection in Sub-Saharan Africa: Does it Spur Industrial Progress?” Economic Development and Cultural Change 52 (2), 393-423.

Shiferaw, A. (2006). "Capital Adjustment Patterns and Uncertainty in African Manufacturing.” ISS Working Paper No. 435, Institute of Social Studies, The Hague.

Söderbom, M., Teal, F., Harding, A. (2006). “ The Determinants of Survival Among African manufacturing Firms." Economic Development and Cultural Change 54 (3), 533-555.

Troske, K. (1989). "The Life-Cycle Behavior of Establishments", Mimeo, University of Chicago.

Tybout, J.R. (2000). "Manufacturing Firms in Developing Countries: How Well Do They Do, and Why?" Journal of Economic Literature 38 (1), 11-44.

Van Biesebroeck, J. (2005). “ Firm Size Matters: Growth and Productivity Growth in African Manufacturing.” Economic Development and Cultural Change 53 (2), 545-583.

World Bank. (2005). World Development Report 2005. A Better Investment Climate for Everyone. New York: Oxford University Press. 
Table 1: Summary Statistics (Industry and Sectoral Averages)

\begin{tabular}{|c|c|c|c|c|c|c|c|c|c|}
\hline & $\begin{array}{l}\text { Food \& } \\
\text { Beverage }\end{array}$ & $\begin{array}{l}\text { Textile \& } \\
\text { Garments }\end{array}$ & $\begin{array}{l}\text { Leather \& } \\
\text { Footwear }\end{array}$ & $\begin{array}{l}\text { Wood \& } \\
\text { Furniture }\end{array}$ & $\begin{array}{l}\text { Printing } \\
\text { \& Paper }\end{array}$ & $\begin{array}{l}\text { Chemical \& } \\
\text { Plastics }\end{array}$ & Non-Metal & $\begin{array}{l}\text { Metal \& } \\
\text { Machinery }\end{array}$ & All Industries \\
\hline Exit Rate & 0.17 & 0.14 & 0.17 & 0.19 & 0.06 & 0.08 & 0.15 & 0.24 & 0.16 \\
\hline Average Firm Size & 45.5 & 117.5 & 62.7 & 30.5 & 30.8 & 52.2 & 23.1 & 27.3 & 44.3 \\
\hline Productivity & 0.98 & 0.93 & 1.45 & 1.04 & 1.13 & 0.98 & 0.97 & 1.14 & 1.04 \\
\hline $\begin{array}{l}\text { Capital Intensity } \\
\text { ('000 Birr per worker) }\end{array}$ & 48.8 & 36.97 & 79.49 & 15.63 & 32.63 & 79.92 & 24.69 & 48.47 & 43.33 \\
\hline Relative Wage & 0.77 & 0.90 & 0.87 & 0.93 & 0.92 & 0.89 & 0.71 & 0.86 & 0.85 \\
\hline Female-Owned & 0.29 & 0.24 & 0.34 & 0.13 & 0.41 & 0.36 & 0.27 & 0.22 & 0.27 \\
\hline Multi-unit & 0.19 & 0.35 & 0.23 & 0.16 & 0.18 & 0.15 & 0.07 & 0.18 & 0.18 \\
\hline FDI & 0.02 & 0.12 & 0.06 & 0.03 & 0.04 & 0.05 & 0.03 & 0.11 & 0.05 \\
\hline Industry Growth Rate & 0.08 & 0.05 & 0.13 & 0.06 & 0.11 & 0.18 & 0.08 & 0.15 & 0.10 \\
\hline Import Penetration Rate & 0.23 & 0.55 & 0.41 & 0.59 & 0.54 & 0.72 & 0.32 & 0.72 & 0.46 \\
\hline Concentration Index & 0.06 & 0.05 & 0.09 & 0.08 & 0.17 & 0.11 & 0.33 & 0.24 & 0.12 \\
\hline Entry Rate & 0.23 & 0.11 & 0.14 & 0.26 & 0.15 & 0.14 & 0.16 & 0.28 & 0.20 \\
\hline Second Hand Market & 0.10 & 0.03 & 0.23 & 0.00 & 0.00 & 0.16 & 0.03 & 0.50 & 0.12 \\
\hline Capital City & 0.62 & 0.77 & 0.88 & 0.47 & 0.82 & 0.90 & 0.43 & 0.75 & 0.66 \\
\hline
\end{tabular}

Source: Author's computation based on CAS's manufacturing census. 
Table 2: Average Characteristics of Surviving and Exiting Private Establishments

\begin{tabular}{lcc}
\hline & $\begin{array}{c}\text { Surviving } \\
\text { Establishments }\end{array}$ & $\begin{array}{c}\text { Exiting } \\
\text { Establishments }\end{array}$ \\
\hline Firm Size & 48.57 & 21.57 \\
Productivity & 1.06 & 0.89 \\
Capital Intensity ('000 Birr) & 46.7 & 27.4 \\
Firm Age & 12.17 & 8.98 \\
Relative Wage & 0.89 & 0.63 \\
Female-Owned & 0.28 & 0.22 \\
Multi-unit & 0.20 & 0.07 \\
FDI & 0.05 & 0.02 \\
\hline Located in Addis Ababa & 0.67 & 0.61 \\
\hline
\end{tabular}

Source: Author's Computation Based on CSA's Manufacturing Census.

A test for equality of means shows that the differences are statistically significant at $1 \%$ for all variables.

Table 3: Results of Discrete Time Proportional Hazard Model (Hazard Ratios)

\begin{tabular}{|c|c|c|c|c|}
\hline 1 & 2 & 3 & 4 & 5 \\
\hline Ln(Labor) & $\begin{array}{l}0.1254 * \star \star \\
(-4.71)\end{array}$ & $\begin{array}{l}0.1171 * \star \star \\
(-5.19)\end{array}$ & $\begin{array}{l}0.1105^{\star * \star} \\
(-4.65)\end{array}$ & $\begin{array}{l}0.1131 * \star \star \\
(-4.61)\end{array}$ \\
\hline$(\operatorname{Ln}(\text { Labor }))^{2}$ & $\begin{array}{l}1.2222^{\star \star \star} \\
(3.21)\end{array}$ & $\begin{array}{l}1.2398 * \star \star \\
(3.66)\end{array}$ & $\begin{array}{l}1.2379 * \star \star \\
(3.17)\end{array}$ & $\begin{array}{l}1.2387 \star \star \star \\
(3.19)\end{array}$ \\
\hline Ln(Establishment age) & $\begin{array}{l}0.8083^{\star \star \star} \\
(-4.27)\end{array}$ & $\begin{array}{l}0.8582 * \star \star \\
(-3.35)\end{array}$ & $\begin{array}{l}0.8154 * \star \star \\
(-4.32)\end{array}$ & $\begin{array}{l}0.8242^{\star \star \star} \\
(-4.08)\end{array}$ \\
\hline Ln(Productivity-GMM) & $\begin{array}{l}0.9233 \\
(-1.50)\end{array}$ & & $\begin{array}{l}0.9045^{\star} \\
(-1.87)\end{array}$ & \\
\hline Ln(Productivity-LP) & & $\begin{array}{l}0.8798 * \star \star \\
(-3.51)\end{array}$ & & $\begin{array}{l}0.8943^{\star \star \star} \\
(-2.64) \\
\end{array}$ \\
\hline Ln(Capital Intensity) & $\begin{array}{l}0.9498 * \star \\
(-2.27)\end{array}$ & $\begin{array}{l}0.9550 * \star \\
(-2.22)\end{array}$ & $\begin{array}{l}0.9431 * \star \\
(-2.47)\end{array}$ & $\begin{array}{l}0.9389 * \star \star \\
(-2.70)\end{array}$ \\
\hline Ln(Relative Wage) & $\begin{array}{l}0.8996^{\star} \\
(-1.83)\end{array}$ & $\begin{array}{l}0.9219 \\
(-1.48)\end{array}$ & $\begin{array}{l}0.9437 \\
(-.90)\end{array}$ & $\begin{array}{l}0.9647 \\
(-0.55)\end{array}$ \\
\hline Female Owned & $\begin{array}{l}0.7450 * \star \star \\
(-2.90)\end{array}$ & $\begin{array}{l}0.7322^{\star \star *} \\
(-2.90)\end{array}$ & $\begin{array}{l}0.7765^{\star \star} \\
(-2.29)\end{array}$ & $\begin{array}{l}0.7720 * * \\
(-2.34)\end{array}$ \\
\hline Multi-unit & $\begin{array}{l}0.5043^{* \star *} \\
(-4.09)\end{array}$ & $\begin{array}{l}0.4402 * \star * \\
(-4.94)\end{array}$ & $\begin{array}{l}0.4724 * \star \star \\
(-4.33)\end{array}$ & $\begin{array}{l}0.4815^{* \star *} \\
(-4.22)\end{array}$ \\
\hline FDI & $\begin{array}{l}0.5880 \\
(-1.56)\end{array}$ & $\begin{array}{l}0.6467 \\
(-1.42)\end{array}$ & $\begin{array}{l}0.6141 \\
(-1.43)\end{array}$ & $\begin{array}{l}0.6084 \\
(-1.45)\end{array}$ \\
\hline Industry Growth Rate & & & $\begin{array}{l}1.0060 * \star \star \\
(3.35)\end{array}$ & $\begin{array}{l}1.0057 \star \star \star \\
(3.18)\end{array}$ \\
\hline Import Penetration Rate & & & $\begin{array}{l}0.9970 \\
(-0.45)\end{array}$ & $\begin{array}{l}0.9962 \\
(-0.58)\end{array}$ \\
\hline Herfindahl Concentration Index & & & $\begin{array}{l}1.6932 * \star \\
(2.50)\end{array}$ & $\begin{array}{l}1.6991 * \star \\
(2.52)\end{array}$ \\
\hline Entry Rate & & & $\begin{array}{l}0.9575^{\star \star \star} \\
(-5.54)\end{array}$ & $\begin{array}{l}0.9576 \star \star \star \\
(-5.54)\end{array}$ \\
\hline Second Hand Market & & & $\begin{array}{l}0.6197^{\star} \\
(-1.89)\end{array}$ & $\begin{array}{l}0.6356^{\star} \\
(-1.79)\end{array}$ \\
\hline Capital City & & & $\begin{array}{l}1.0244 \\
(0.23)\end{array}$ & $\begin{array}{l}1.0060 \\
(0.06)\end{array}$ \\
\hline Industry dummies & (No) & (No) & (Yes) & (Yes) \\
\hline Observations (firm-years) & 3339 & 3759 & 3187 & 3187 \\
\hline Log-Likelihood & -1319.18 & -1502.03 & -1197.69 & -1195.97 \\
\hline
\end{tabular}

Note: $* * *, * * *$ represent statistical significance at $10 \%, 5 \%$, and $1 \%$. Figure in parenthesis are $\mathrm{z}$-statistics from the underlying regression. 
Table 4: Hazard Ratios with Unobserved Heterogeneity

\begin{tabular}{|c|c|c|}
\hline 1 & 2 & 3 \\
\hline Ln(Labor) & $\begin{array}{c}0.1483 * * * \\
(-2.95)\end{array}$ & $\begin{array}{c}0.0719 * * * \\
(-4.56)\end{array}$ \\
\hline$(\operatorname{Ln}(\text { Labor }))^{2}$ & $\begin{array}{c}1.1759^{*} \\
(1.81)\end{array}$ & $\begin{array}{c}1.2951^{* * *} \\
(3.27)\end{array}$ \\
\hline Ln(Establishment age) & $\begin{array}{l}0.9203 \\
(-1.14) \\
\end{array}$ & \\
\hline Ln(Duration) & & $\begin{array}{c}0.2857^{* * *} \\
(-7.46) \\
\end{array}$ \\
\hline Ln(Productivity-GMM) & $\begin{array}{c}0.8298 * * * \\
(-2.65)\end{array}$ & $\begin{array}{c}0.8636^{* *} \\
(-2.39)\end{array}$ \\
\hline Ln(Capital Intensity) & $\begin{array}{c}0.9326^{*} \\
(-1.76) \\
\end{array}$ & $\begin{array}{l}0.9792 \\
(-0.70)\end{array}$ \\
\hline Ln(Relative Wage) & $\begin{array}{l}0.9332 \\
(-0.79)\end{array}$ & $\begin{array}{c}0.8743^{*} \\
(-1.78)\end{array}$ \\
\hline Female Owned & $\begin{array}{c}0.7325^{* *} \\
(2.03)\end{array}$ & $\begin{array}{c}0.7486 * * \\
(-2.08)\end{array}$ \\
\hline Multi-unit & $\begin{array}{c}0.3249 * * * \\
(-5.02)\end{array}$ & $\begin{array}{c}0.3314 * * * \\
(-4.43)\end{array}$ \\
\hline FDI & $\begin{array}{l}0.6578 \\
(-1.01) \\
\end{array}$ & $\begin{array}{l}0.5798 \\
(-1.41) \\
\end{array}$ \\
\hline Industry Growth Rate & $\begin{array}{c}1.0099^{* * *} \\
(4.25)\end{array}$ & $\begin{array}{c}1.0109 * * * \\
(4.99)\end{array}$ \\
\hline Import Penetration Rate & $\begin{array}{l}1.0057 \\
(0.58)\end{array}$ & $\begin{array}{c}1.0209 * * \\
(2.50)\end{array}$ \\
\hline Herfindahl Concentration Index & $\begin{array}{l}1.1819 \\
(0.67)\end{array}$ & $\begin{array}{l}0.7062 \\
(-1.35)\end{array}$ \\
\hline Entry Rate & $\begin{array}{c}0.9349 * * * \\
(-6.7)\end{array}$ & $\begin{array}{c}0.9229 * * * \\
(-6.98)\end{array}$ \\
\hline Second Hand Market & $\begin{array}{c}0.4302^{* *} \\
(-2.06) \\
\end{array}$ & $\begin{array}{c}0.4435^{* *} \\
(-2.53) \\
\end{array}$ \\
\hline Capital City & $\begin{array}{l}0.8763 \\
(-0.76)\end{array}$ & $\begin{array}{l}1.0015 \\
(0.01)\end{array}$ \\
\hline Industry Dummies & (Yes) & (Yes) \\
\hline Observations (firm-years) & 3187 & 3187 \\
\hline Log-Likelihood & -1170.56 & -1171.73 \\
\hline
\end{tabular}

Authors computation based on Ethiopian manufacturing census.

$*, * *, * * *$ represent statistical significance at $10 \%, 5 \%$, and $1 \%$. Figure in parenthesis are zstatistics from the underlying regression. 


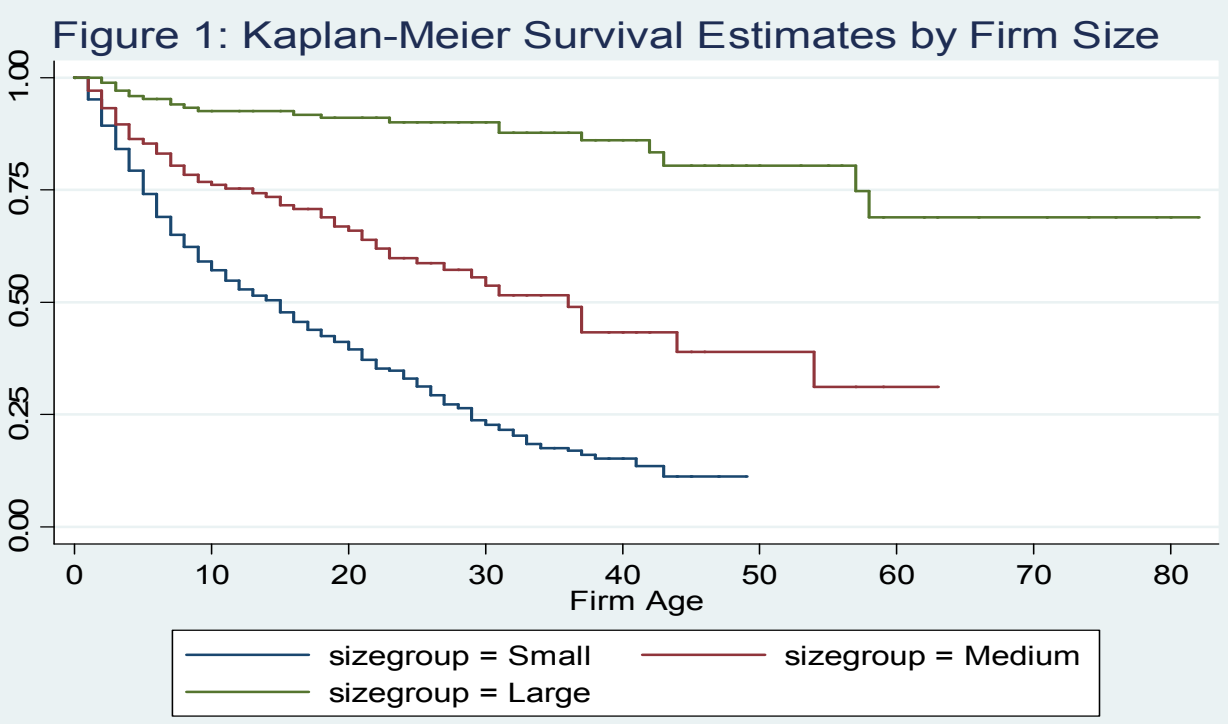

Source: Author's Computation Based on CSA's Manufacturing Census. 
Appendix Table 1: System GMM Estimates of Value Added Production Functions

\begin{tabular}{|c|c|c|c|c|c|c|c|}
\hline Industry & $\begin{array}{l}\text { Lag Value } \\
\text { Added }\end{array}$ & Labor & Capital & $\begin{array}{l}\text { M1 } \\
\text { (p-value) }\end{array}$ & $\begin{array}{l}\text { M2 } \\
\text { (p-value) }\end{array}$ & $\begin{array}{l}\text { Hansen } \\
\text { test } \\
\text { (p-value) }\end{array}$ & $\begin{array}{l}\text { Sample Size } \\
\text { (firm-years) }\end{array}$ \\
\hline $\begin{array}{r}\text { Food \& } \\
\text { Beverage }\end{array}$ & $\begin{array}{r}0.3457 \\
(0.1790)\end{array}$ & $\begin{array}{r}0.5229 \\
(0.1975)\end{array}$ & $\begin{array}{r}0.2329 \\
(0.1243)\end{array}$ & 0.0020 & 0.899 & 0.570 & 823 \\
\hline $\begin{array}{r}\text { Textile \& } \\
\text { Garments }\end{array}$ & $\begin{array}{r}0.0963 \\
(0.1088)\end{array}$ & $\begin{array}{r}0.9282 \\
(0.1978)\end{array}$ & $\begin{array}{r}0.1112 \\
(0.1212)\end{array}$ & 0.0150 & 0.632 & 0.255 & 298 \\
\hline $\begin{array}{l}\text { Leather \& } \\
\text { Footwear }\end{array}$ & $\begin{array}{r}-0.1174 \\
(0.1633) \\
\end{array}$ & $\begin{array}{r}1.0229 \\
(0.2324) \\
\end{array}$ & $\begin{array}{r}0.4362 \\
(0.1340) \\
\end{array}$ & 0.0820 & 0.721 & 0.811 & 198 \\
\hline $\begin{array}{l}\text { Wood \& } \\
\text { Furniture }\end{array}$ & $\begin{array}{r}-0.0435 \\
(0.1437) \\
\end{array}$ & $\begin{array}{r}1.3696 \\
(0.2033) \\
\end{array}$ & $\begin{array}{r}0.0338 \\
(0.0892) \\
\end{array}$ & 0.0270 & 0.919 & 0.804 & 555 \\
\hline $\begin{array}{r}\text { Printing \& } \\
\text { Paper } \\
\end{array}$ & $\begin{array}{r}0.2671 \\
(0.1615) \\
\end{array}$ & $\begin{array}{r}0.7625 \\
(0.2891) \\
\end{array}$ & $\begin{array}{r}0.0103 \\
(0.0474) \\
\end{array}$ & 0.0130 & 0.808 & 0.588 & 256 \\
\hline $\begin{array}{r}\text { Chemical \& } \\
\text { Plastics } \\
\end{array}$ & $\begin{array}{r}0.5022 \\
(0.1620) \\
\end{array}$ & $\begin{array}{r}0.0757 \\
(0.2635) \\
\end{array}$ & $\begin{array}{r}0.3032 \\
(0.1698) \\
\end{array}$ & 0.0140 & 0.796 & 0.699 & 311 \\
\hline Non-metal & $\begin{array}{r}0.1189 \\
(0.1364) \\
\end{array}$ & $\begin{array}{r}1.1055 \\
(0.2047) \\
\end{array}$ & $\begin{array}{r}0.0797 \\
(0.1024) \\
\end{array}$ & 0.0320 & 0.710 & 0.821 & 320 \\
\hline $\begin{array}{r}\text { Metal \& } \\
\text { machinery }\end{array}$ & $\begin{array}{r}0.3447 \\
(0.1144)\end{array}$ & $\begin{array}{r}0.6994 \\
(0.1806)\end{array}$ & $\begin{array}{r}0.3939 \\
(0.1587)\end{array}$ & 0.0130 & 0.421 & 0.572 & 282 \\
\hline
\end{tabular}

Note: Figures in parenthesis are standard errors. The Hansen test is a chi-square test for overidentification and it shows that the instrument sets are not correlated with the equation errors. M1 and M2 report, respectively, the statistical test for the null hypothesis that there is no first- and second-order autocorrelation in the first-difference of the transient error term. The results indicate the presence of first-order autocorrelation but no second-order autocorrelation in the first-differenced error term. Except the Leather and footwear, and the chemical and plastic industries, we cannot reject constant returns to scale. 
Appendix Table 2: Descriptive Statistics Over Time

\begin{tabular}{|c|c|c|c|c|c|c|c|c|}
\hline & 1996 & 1997 & 1998 & 1999 & 2000 & 2001 & 2002 & Average \\
\hline Exit Rate & 0.18 & 0.21 & 0.16 & 0.24 & 0.16 & 0.19 & na & 0.16 \\
\hline Firm Size & 42.17 & 41.20 & 41.74 & 43.83 & 45.63 & 49.22 & 45.44 & 44.33 \\
\hline Relative Efficiency & $\mathrm{Na}$ & 1.08 & 1.09 & 1.03 & 1.06 & 0.98 & 1.05 & 1.04 \\
\hline Capital intensity & 28.55 & 30.77 & 36.18 & 44.67 & 45.50 & 52.79 & 57.96 & 43.34 \\
\hline Relative Wage & 0.82 & 0.84 & 0.83 & 0.84 & 0.87 & 0.85 & 0.86 & 0.85 \\
\hline Female Owned & 0.22 & 0.24 & 0.24 & 0.26 & 0.26 & 0.35 & 0.29 & 0.27 \\
\hline Multi-unit & 0.16 & 0.16 & 0.19 & 0.18 & 0.20 & 0.20 & 0.18 & 0.18 \\
\hline FDI & 0.05 & 0.04 & 0.03 & 0.05 & 0.04 & 0.06 & 0.06 & 0.05 \\
\hline Industry Growth & 14.13 & 13.97 & 3.03 & 12.65 & 9.04 & 16.65 & 0.18 & 9.60 \\
\hline Import & 45.90 & 36.56 & 37.84 & 39.15 & 39.17 & 44.35 & 42.95 & 46.49 \\
\hline Concentration & 0.15 & 0.14 & 0.14 & 0.11 & 0.13 & 0.11 & 0.10 & 0.12 \\
\hline Entry Rate & & 27.17 & 22.68 & 15.26 & 20.85 & 12.86 & 25.04 & 20.65 \\
\hline Second Hand & 0.07 & 0.07 & 0.09 & 0.09 & 0.10 & 0.11 & 0.09 & 0.09 \\
\hline Capital City & 0.72 & 0.68 & 0.68 & 0.65 & 0.66 & 0.64 & 0.63 & 0.66 \\
\hline No. Establishments & 448 & 536 & 567 & 588 & 591 & 611 & 694 & 4035 \\
\hline
\end{tabular}

Source: Author's computation based on CSA's manufacturing census.

Note: Figures are annul averages for the private manufacturing sector. The last column is average for the private sector for the entire sample period.

$\mathrm{Na}$ : not available. In the case of exit it is due to truncation while for productivity it is because of the lag structure in the production function. 